\title{
Developmental malformations in Huntington disease: neuropathologic evidence of focal neuronal migration defects in a subset of adult brains
}

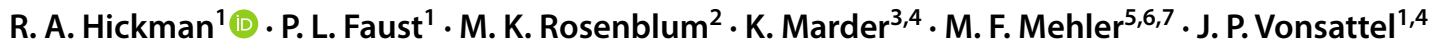

Received: 27 October 2020 / Revised: 27 December 2020 / Accepted: 19 January 2021 / Published online: 30 January 2021

(c) The Author(s) 2021

\begin{abstract}
Neuropathologic hallmarks of Huntington Disease (HD) include the progressive neurodegeneration of the striatum and the presence of Huntingtin (HTT) aggregates that result from abnormal polyQ expansion of the HTT gene. Whether the pathogenic trinucleotide repeat expansion of the HTT gene causes neurodevelopmental abnormalities has garnered attention in both murine and human studies; however, documentation of discrete malformations in autopsy brains of HD individuals has yet to be described. We retrospectively searched the New York Brain Bank (discovery cohort) and an independent cohort (validation cohort) to determine whether developmental malformations are more frequently detected in HD versus non-HD brains and to document their neuropathologic features. One-hundred and thirty HD and 1600 non-HD whole brains were included in the discovery cohort and $720 \mathrm{HD}$ and 1989 non-HD half brains were assessed in the validation cohort. Cases with developmental malformations were found at 6.4-8.2 times greater frequency in HD than in non-HD brains (discovery cohort: OR $8.68,95 \%$ CI $3.48-21.63, P=4.8 \times 10^{-5}$; validation cohort: OR 6.50, 95\% CI 1.83-23.17, $P=0.0050$ ). Periventricular nodular heterotopias (PNH) were the most frequent malformations and contained HTT and p62 aggregates analogous to the cortex, whereas cortical malformations with immature neuronal populations did not harbor such inclusions. HD individuals with malformations had heterozygous HTT CAG expansions between 40 and 52 repeats, were more frequently women, and all were asymmetric and focal, aside from one midline hypothalamic hamartoma. Using two independent brain bank cohorts, this large neuropathologic series demonstrates an increased occurrence of developmental malformations in HD brains. Since pathogenic $H T T$ gene expansion is associated with genomic instability, one possible explanation is that neuronal precursors are more susceptible to somatic mutation of genes involved in cortical migration. Our findings further support emerging evidence that pathogenic trinucleotide repeat expansions of the HTT gene may impact neurodevelopment.
\end{abstract}

Keywords Huntington disease $\cdot$ Heterotopia $\cdot$ Malformation $\cdot$ Hamartoma $\cdot$ Development $\cdot$ Huntingtin

R. A. Hickman

rh2850@cumc.columbia.edu

1 Department of Pathology and Cell Biology, Columbia University Irving Medical Center and New York Presbyterian Hospital, New York, USA

2 Department of Pathology, Memorial Sloan Kettering Cancer Center, New York, USA

3 Department of Neurology and Psychiatry, Columbia University Irving Medical Center, New York, USA
4 Taub Institute for Research on Alzheimer's disease and the Aging Brain, Columbia University Medical Center, 710 West 168th Street, New York, NY 10032, USA

5 The Saul R. Korey Department of Neurology, Albert Einstein College of Medicine, New York, USA

6 Dominick P. Purpura Department of Neuroscience, Albert Einstein College of Medicine, New York, USA

7 Department of Psychiatry and Behavioral Sciences, Albert Einstein College of Medicine, New York, USA 


\section{Introduction}

Increasing attention has been afforded to the neurodevelopmental abnormalities in Huntington Disease (HD) and its possible contributions to neurodegeneration [3, 10, 41, 42, 47]. The pathogenic CAG repeat expansion in the HTT gene that causes HD exists from conception and continues to be expressed throughout development and the remainder of life [11, 38]. Healthy development depends on the gene's encoded protein, Huntingtin (HTT), which has vital roles in gastrulation and corticogenesis [6, 16, 25, 64]. Homozygous HTT knockout mice cannot develop beyond mid-embryonic stages (E7.5-8.5) and HTT hypomorphic mice exhibit neuronal migration defects with later striatal degeneration [5, 20, 45]. Limited data in humans suggest that there are developmental differences in gene-expanded carriers (GEC). The rate of brain growth is reduced in GEC and there is a tendency for smaller intracranial volumes when compared to age-matched control subjects [35, 47, 60]. Furthermore, brains of human fetal GEC have wide-ranging anomalies in corticogenesis. At 13 weeks gestational age, HTT and junctional complex proteins are mislocalized at the ventricular zone, and neural progenitor cells exhibit various defects, including abnormalities in cellular polarity, differentiation, and ciliogenesis [10].

However, despite these emerging data, there has been no reported evidence of malformations due to either patterning defects or neuronal migration disorders in adult human post-mortem HD brains. While the exact frequency of cortical malformations in the general population is unknown, they are considered to be rare; the most commonly detected malformation are periventricular nodular heterotopias (PNH) $[4,8,52]$. Gray matter heterotopias are characterized by abnormally located islands of gray matter within white matter that are the result of aborted neuronal migration during cortical development [9]. Although infrequent, they have been reported in large neurodegenerative brain bank cohorts and can share the proteinopathies found within the cortex $[12,31]$.

We hypothesized that malformations are more frequent in brains of individuals with HD than those without. We searched the database at the New York Brain Bank (NYBB) between 2001 and 2020 for malformations and reviewed their neuropathologic characteristics. The standardized brain bank protocol used at the NYBB permits consistent comparisons across neurodegenerative diseases and controls without otherwise introducing sampling biases across brains. We find that malformations are more frequent in HD brains than non-HD brains at the NYBB and this observation is replicated in another larger autopsy cohort. Similar to other neurodegenerative diseases with distinctive proteinopathies, HTT and p62 aggregates can coexist within the cerebral cortex and heterotopias. The implications of this increased occurrence of developmental anomalies in HD and their relationship to the expanded HTT gene are discussed.

\section{Materials and methods}

\section{Study subjects and dissection protocol}

The majority of brains included in the discovery cohort (NYBB) were processed using the standardized protocol as outlined previously [62]. Most fresh brains were divided by a sagittal cut through the corpus callosum and brainstem resulting in two half brains; one half brain would then be processed for banking of fresh-frozen samples for research. A pathologist macroscopically examined all fresh brain slices. The non-banked half or whole brain was then fixed by immersion in $10 \%$ neutral-buffered formalin solution for 2 weeks and then evaluated as per the NYBB protocol. Briefly, the cerebral hemispheres were sectioned in the coronal plane, the brainstem in the transverse plane, and cerebellum in the sagittal plane. All sections were performed at 0.3 $\mathrm{cm}$ intervals. The Brodmann map was utilized for blocking cortical regions to allow for consistent comparisons of neocortical regions across brains [14]. A standardized series of formalin-fixed tissue blocks was then processed, embedded in paraffin wax and sectioned at $7 \mu \mathrm{m}$ thickness. The vast majority of cases were examined and diagnosed by one of the authors who has extensive expertise in neurodegenerative disease (JPV).

The validation cohort represented an independent cohort of brains that were examined by one of the authors (JPV) before 2001 at the Harvard Brain Tissue Resource Center (HBTRC) at McLean Hospital, Boston, USA. This cohort of brains often had one half brain either frozen en bloc or dissected by a research technician, while the other fixed half brain was macroscopically and microscopically examined by a neuropathologist.

All brain donors were consented for autopsy and brain donation. All procedures performed were in accordance with the ethical standards of the institution and with the 1964 Helsinki declaration and its later amendments. This study is considered exempt from Columbia's institutional review board, since it utilizes only post-mortem human tissues.

\section{Database searches}

The discovery cohort was assembled from brains banked at the NYBB between 2001 and 2020. The relational database used at the NYBB is a customized archive of data that uses the scripting language of FileMaker Pro to contain all specimens that have been studied at the NYBB [32]. Of 
1766 cases, 1731 cases met the inclusion criteria of having an intact brain specimen that was macroscopically and microscopically examined. In May 2020, this database was searched using the keyword search terms, "heterotopia" and "malformation". One case with a heterotopia was excluded, because the individual had a genetic predisposition for developmental malformations. Twenty cases were identified and histology slides were reassessed. Then, 12 cases with malformations of the following conditions were assessed in the non-HD cohort: (1) Alzheimer Disease neuropathologic changes (ADNC) with or without Lewy body-containing neurons, (2) Diffuse Lewy body disease (DLBD)/Parkinson Disease (PD) with or without ADNC, and (3) Cases without neurodegenerative disease (control). Histologic changes associated with aging, such as primary age-related tauopathy [28] or age-related vascular disease, were included in this latter group.

A second database using Microsoft Excel comprised the cohort of brains assessed by one of the authors (JPV) between 1981 and 2000 at the HBTRC. This anonymized database included age, sex, whether a half brain or whole brain was examined by a pathologist, and the primary neuropathologic diagnoses of each brain. After excluding consult cases, the database was searched for the proportion of half brains examined by a pathologist that harbored a brain malformation in HD and non-HD cases. Additionally, the non-HD groups were then subdivided into three further categories as follows: (1) Cases with ADNC with or without DLBD/PD, (2) DLB/PD with or without ADNC, and (3) Controls, defined as cases without neurodegenerative disease as outlined in the validation cohort.

\section{Histochemical staining protocols}

Luxol-fast blue counterstained with hematoxylin and eosin sections were examined. Paraffin sections of ten cases (\#1-5, \#7-8, \#13, \#16, and \#18) were immunostained on an automated immunostaining platform using a DAB with or without alkaline phosphatase dual staining system on a Roche Ventana staining platform (Table 1). Hematoxylin counterstains were performed. We used the 2B4 anti-HTT antibody that targets a.a. 1-82 of the N-terminal end of HTT; this antibody has been validated in human HD brains [18, 27]. The anti-CD34 antibody (QBEND/10 clone) targets a.a. 43-49 of the extracellular domain and is expressed in stem cells as well as endothelial cells [2].

\section{Statistical analyses}

Statistical analyses were performed on GraphPad Prism version 8.4.2 and IBM SPSS $®$ Statistics software version 27. Statistical comparisons between the demographic distribution and frequency of malformations of HD and nonHD groups were performed using two-sided Fisher's exact tests (Supplemental Table 1). Odds ratios (OR) and 95\% confidence intervals (CI) were determined using the Baptista-Pike method. For a final overall model, we applied binary logistic regression to both cohorts with malformation as the dependent variable to examine the interactions of age at death, sex, and HD status. One-hundred and thirty-one of 4049 participants lacked data for age and/ or sex (43 HD and 88 non-HD) and were therefore excluded from this analysis. Then, to explore the association between sex and age at death with malformation in HD, binary logistic regression was assessed only in HD participants using the combined cohort. Thirty-eight participants lacked data for age and/or sex and were thus excluded in this latter assessment.

Throughout this study, a $P$ value $<0.05$ was deemed statistically significant.

\section{Results}

\section{Malformations are more frequent in HD than non-HD brains}

1730 brains were included in the discovery cohort and the demographic details are provided in Supplemental Table 1. Of these, 130 brains were diagnosed as HD and $6.2 \%$ had at least one malformation that was either a periventricular nodular heterotopia $(n=4)$, multinodular and vacuolating neuronal tumor of the cerebrum (MVNT) $(n=1)$, a

Table 1 Details regarding primary immunohistochemical stains used in this study

\begin{tabular}{|c|c|c|c|c|c|c|c|}
\hline Antibody & Company & Catalogue number & Dilution & $\begin{array}{l}\text { Primary antibody } \\
\text { incubation time } \\
\text { (min) }\end{array}$ & Protocol & Platform & Chromagen \\
\hline $\begin{array}{l}\text { Huntingtin/ } \\
\text { p62 double } \\
\text { stain }\end{array}$ & Millipore/Abcam & $\begin{array}{r}\text { MAB5492/ } \\
\text { ab207305 }\end{array}$ & 1:2000 each & $32 / 24$ & $64 \min (\mathrm{CC} 1)$ & $\begin{array}{l}\text { Roche Ventana } \\
\text { Instrument }\end{array}$ & $\begin{array}{l}\text { Brown- Huntingtin } \\
\text { Red-p62 }\end{array}$ \\
\hline Huntingtin & Millipore & MAB5492 & $1: 2000$ & 32 & $64 \min (\mathrm{CC} 1)$ & & Brown \\
\hline P62 & Abcam & Ab207305 & $1: 2000$ & 24 & $64 \min (\mathrm{CC} 1)$ & & Brown \\
\hline CD34 & Leica & PA0212 & Predilute & 30 & $20 \min (\mathrm{ER} 2)$ & Leica Bond III & Brown \\
\hline
\end{tabular}


glioneuronal hamartoma ( $n=1)$, or a cerebellar nodular heterotopia $(n=2)$. This frequency was 8.2 -fold greater than that found in non-HD brains $(0.75 \%, n=12$ of 1600 , OR $8.68,95 \%$ CI 3.48-21.63, $P=4.8 \times 10^{-5}$, two-sided Fisher's exact test). Aside from the midline hamartoma (case \#4), all HD malformations were asymmetric and solitary. Individuals with malformations in this discovery cohort are shown in Table 2. Other malformations, such as tubers or type II focal cortical dysplasia, were not recognized.

To replicate our findings, we assessed the files of an independent cohort of 2709 half brains, of which 720 were half brains from HD individuals that were received at the HBTRC (Table 3; Supplemental Table 1). Seven of 720 $(0.97 \%)$ HD half brains had heterotopias whereas only 3

Table 2 Demographics, clinical information and locations of malformations between HD versus non-HD brains of the discovery cohort

\begin{tabular}{|c|c|c|c|c|c|c|c|}
\hline Group & Case \# & $\begin{array}{l}\text { Age at } \\
\text { death } \\
\text { (years) }\end{array}$ & Sex & $\begin{array}{l}\text { CAG repeat length } \\
\text { of expanded allele }\end{array}$ & Post-mortem diagnosis & Location & Malformation type \\
\hline \multirow[t]{8}{*}{ HD } & 1 & 41 & Woman & 47 & HD $3 / 4 *$ & Atrium, left & $\begin{array}{l}\text { Periventricular nodular } \\
\text { heterotopia }\end{array}$ \\
\hline & 2 & 68 & Woman & 44 & HD $3 / 4$ & $\begin{array}{l}\text { Roof of temporal horn of } \\
\text { lateral ventricle, left }\end{array}$ & $\begin{array}{l}\text { Periventricular nodular } \\
\text { heterotopia }\end{array}$ \\
\hline & 3 & 58 & Woman & Unknown & HD 3/4 & $\begin{array}{l}\text { Above tail of caudate } \\
\text { nucleus, left }\end{array}$ & $\begin{array}{l}\text { Periventricular nodular } \\
\text { heterotopia }\end{array}$ \\
\hline & 4 & 59 & Woman & 42 & HD 3/4 & Tuber cinereum & Hypothalamic hamartoma \\
\hline & 5 & 75 & Woman & 42 & $\mathrm{HD} 2 / 4$ & $\begin{array}{l}\text { Prefrontal subcortical } \\
\text { white matter, left }\end{array}$ & $\begin{array}{l}\text { Multinodular and vacuolat- } \\
\text { ing neuronal tumor of the } \\
\text { cerebrum (MVNT) }\end{array}$ \\
\hline & 6 & 72 & Man & 40 & HD 2/4 & $\begin{array}{l}\text { Cerebellar white matter, } \\
\text { left }\end{array}$ & $\begin{array}{l}\text { Cerebellar nodular hetero- } \\
\text { topia }\end{array}$ \\
\hline & 7 & 72 & Woman & Unknown & HD $1 / 4$ & $\begin{array}{l}\text { Cerebellar white matter, } \\
\text { left }\end{array}$ & $\begin{array}{l}\text { Cerebellar nodular hetero- } \\
\text { topia }\end{array}$ \\
\hline & 8 & 36 & Woman & 52 & HD $4 / 4$ & $\begin{array}{l}\text { 1) Above tail of caudate } \\
\text { nucleus, right } \\
\text { 2) Insular cortex, right }\end{array}$ & $\begin{array}{l}\text { 1) Periventricular nodular } \\
\text { heterotopia } \\
\text { 2) Glial microhamartoma/ } \\
\text { heterotopia }\end{array}$ \\
\hline \multirow[t]{12}{*}{ Non-HD } & 9 & 92 & Woman & N/A & $\mathrm{ADNC}$ & $\begin{array}{l}\text { Frontal subcortical white } \\
\text { matter, left }\end{array}$ & $\begin{array}{l}\text { Periventricular nodular } \\
\text { heterotopia }\end{array}$ \\
\hline & 10 & 91 & Man & & $\mathrm{ADNC}$ & $\begin{array}{l}\text { Superolateral angle of the } \\
\text { lateral ventricle, left }\end{array}$ & $\begin{array}{l}\text { Periventricular nodular } \\
\text { heterotopia }\end{array}$ \\
\hline & 11 & 79 & Woman & & ADNC & $\begin{array}{l}\text { Prefrontal subcortical } \\
\text { white matter, left }\end{array}$ & $\begin{array}{l}\text { Subcortical nodular hetero- } \\
\text { topia }\end{array}$ \\
\hline & 12 & 86 & Man & & $\mathrm{ADNC}$ & Roof of temporal horn & $\begin{array}{l}\text { Periventricular nodular } \\
\text { heterotopia }\end{array}$ \\
\hline & 13 & 90 & Woman & & $\mathrm{ADNC}$ & $\begin{array}{l}\text { Temporal pole, subcortical } \\
\text { white matter, left }\end{array}$ & Subcortical band heterotopia \\
\hline & 14 & 67 & Woman & & $\mathrm{ADNC}$ & Alveus, hippocampus, left & $\begin{array}{l}\text { Periventricular nodular } \\
\text { heterotopia }\end{array}$ \\
\hline & 15 & 74 & Man & & Control & Frontal, right & $\begin{array}{l}\text { Multiple heterotopia, nodu- } \\
\text { lar and band }\end{array}$ \\
\hline & 16 & 66 & Man & & Control & $\begin{array}{l}\text { Superolateral angle of } \\
\text { lateral ventricle, right }\end{array}$ & $\begin{array}{l}\text { Periventricular nodular } \\
\text { heterotopia }\end{array}$ \\
\hline & 17 & 90 & Man & & ADNC & $\begin{array}{l}\text { Temporal pole, subcortical } \\
\text { white matter, left }\end{array}$ & MVNT \\
\hline & 18 & 80 & Man & & $\mathrm{DLB} / \mathrm{PD}$ & $\begin{array}{l}\text { Optic radiation, temporal, } \\
\text { left }\end{array}$ & $\begin{array}{l}\text { Periventricular nodular } \\
\text { heterotopia }\end{array}$ \\
\hline & 19 & 81 & Man & & Multi-infarct dementia & Cerebral leptomeninges & $\begin{array}{l}\text { Leptomeningeal gli- } \\
\text { oneuronal heterotopias, } \\
\text { multifocal }\end{array}$ \\
\hline & 20 & 93 & Woman & & ADNC & $\begin{array}{l}\text { Cerebellar white matter, } \\
\text { left }\end{array}$ & $\begin{array}{l}\text { Cerebellar nodular hetero- } \\
\text { topia }\end{array}$ \\
\hline
\end{tabular}

* Refers to Vonsattel grade of HD [63] 
Table 3 Demographics, clinical information, and locations of heterotopias between HD versus non-HD brains of the validation cohort.

\begin{tabular}{|c|c|c|c|c|c|c|c|}
\hline Group & Case \# & $\begin{array}{l}\text { Age at } \\
\text { death } \\
\text { (years) }\end{array}$ & Sex & $\begin{array}{l}\text { CAG repeat length } \\
\text { of expanded allele }\end{array}$ & Post-mortem diagnosis & Location & Malformation type \\
\hline \multirow[t]{7}{*}{ HD } & 21 & 75 & Man & Unknown & $\mathrm{HD}, 3 / 4 *$ & Roof of temporal horn & $\begin{array}{l}\text { Periventricular nodular } \\
\text { heterotopia }\end{array}$ \\
\hline & 22 & 47 & Woman & Unknown & $\mathrm{HD}, 4 / 4$ & Roof of temporal horn, right & $\begin{array}{l}\text { Periventricular nodular } \\
\text { heterotopia }\end{array}$ \\
\hline & 23 & 58 & Man & Unknown & $\mathrm{HD}, 4 / 4$ & $\begin{array}{l}\text { Superolateral angle of lateral } \\
\text { ventricle, frontal, left }\end{array}$ & $\begin{array}{l}\text { Periventricular nodular } \\
\text { heterotopia }\end{array}$ \\
\hline & 24 & 69 & Woman & 40 & $\mathrm{HD}, 4 / 4$ & Roof of temporal horn, right & $\begin{array}{l}\text { Periventricular nodular } \\
\text { heterotopia }\end{array}$ \\
\hline & 25 & 36 & Woman & Unknown & $\mathrm{HD}, 1 / 4$ & Cerebellar white matter, left & $\begin{array}{l}\text { Cerebellar nodular het- } \\
\text { erotopia }\end{array}$ \\
\hline & 26 & 60 & Woman & Unknown & $\mathrm{HD}, 3 / 4$ & Roof of temporal horn, left & $\begin{array}{l}\text { Periventricular nodular } \\
\text { heterotopia }\end{array}$ \\
\hline & 27 & 49 & Woman & Unknown & $\mathrm{HD}, 2 / 4$ & Roof of temporal horn, right & $\begin{array}{l}\text { Periventricular nodular } \\
\text { heterotopia }\end{array}$ \\
\hline \multirow[t]{3}{*}{$\begin{array}{r}\text { Non- } \\
\text { HD }\end{array}$} & 28 & 71 & Woman & N/A & Control & Parietal white matter, right & $\begin{array}{l}\text { Periventricular nodular } \\
\text { heterotopia }\end{array}$ \\
\hline & 29 & 91 & Man & & ADNC & Roof of temporal horn, right & $\begin{array}{l}\text { Periventricular nodular } \\
\text { heterotopia }\end{array}$ \\
\hline & 30 & 43 & Man & & $\begin{array}{l}\text { Hippocampal sclero- } \\
\text { sis (schizophrenia, } \\
\text { clinical) }\end{array}$ & Roof of temporal horn, right & $\begin{array}{l}\text { Periventricular nodular } \\
\text { heterotopia }\end{array}$ \\
\hline
\end{tabular}

ADNC Alzheimer disease neuropathologic changes

*Refers to Vonsattel grade of HD [63]

of $1989(0.15 \%)$ non-HD half brains had such malformations. Although the overall detection of malformations was approximately three times less than in the discovery cohort, heterotopias in HD were still 6.4 times more frequent in HD than non-HD half brains (OR 6.50, 95\% CI 1.83-23.17, $P=0.0050$, two-sided Fisher's exact test), akin to that found in the discovery cohort.
Further subdivisions of malformation frequency between both cohorts are shown in Table 4. In the discovery cohort, the frequencies of malformations in HD were significantly greater than all of the other categories. In the validation cohort, the frequency of malformations was also significantly greater in HD brains than in non-HD and in ADNC brains with similar odds ratios to that of the discovery

Table 4 Comparisons of malformation frequency between HD and other diseases/controls in the cohorts.

\begin{tabular}{|c|c|c|c|c|c|c|c|c|}
\hline \multirow{3}{*}{$\begin{array}{l}\text { Proportion with } \\
\text { malformations }\end{array}$} & \multicolumn{4}{|c|}{ Discovery cohort } & \multicolumn{4}{|c|}{ Validation cohort } \\
\hline & HD & Non-HD & $P$ & $\mathrm{OR}(\mathrm{CI})$ & HD & Non-HD & $P$ & $\mathrm{OR}(\mathrm{CI})$ \\
\hline & $8 / 130(6.15 \%)$ & $12 / 1600(0.75 \%)$ & $4.8 \times 10^{-5}$ & $\begin{array}{c}8.68(3.48- \\
21.63)\end{array}$ & $7 / 720(0.97 \%)$ & $3 / 1989(0.15 \%)$ & 0.0050 & $6.50(1.83-23.17)$ \\
\hline & & $\mathrm{ADNC}$ & $P$ & $\mathrm{OR}(\mathrm{CI})$ & & ADNC & $P$ & $\mathrm{OR}(\mathrm{CI})$ \\
\hline & & $8 / 685(1.17 \%)$ & 0.0014 & $\begin{array}{l}5.55(2.06- \\
14.88)\end{array}$ & & $1 / 798(0.12 \%)$ & 0.031 & $7.83(1.18-88.3)$ \\
\hline & & DLB/ PD & $P$ & $\mathrm{OR}(\mathrm{CI})$ & & DLB/PD & $P$ & OR (CI) \\
\hline & & $1 / 212(0.47 \%)$ & 0.0023 & $\begin{array}{c}13.84(2.09- \\
154.3)\end{array}$ & & $0 / 118(0 \%)$ & 0.60 & - \\
\hline & & Control & $P$ & $\mathrm{OR}(\mathrm{CI})$ & & Control & $P$ & $\mathrm{OR}(\mathrm{CI})$ \\
\hline & & $2 / 235(0.85 \%)$ & 0.0049 & $\begin{array}{l}7.64(1.84- \\
36.03)\end{array}$ & & $1 / 626(0.16 \%)$ & 0.075 & $6.14(0.8-69.27)$ \\
\hline
\end{tabular}

In contrast to the discovery cohort, where the figures represent the total number of whole brains examined, the figures in the validation cohort represent the total number of half brains. $P$ values represent two-sided Fisher's exact tests comparing the frequency of heterotopias in HD and that of the other respective conditions. 
cohort. However, significance could not be achieved in the DLB/PD and control groups, probably because they were underpowered.

In the discovery cohort, malformations were more frequent in women $(11.5 \%)$ than in men $(1.4 \%)$ with HD (OR $8.82,95 \%$ CI 1.48-100.6, $P=0.026$, two-sided Fisher's exact test). This was in contrast to brains without HD where there was no significant difference between women $(0.6 \%)$ and men $(0.9 \%)$ with malformations (OR $0.72,95 \%$ CI $0.26-2.04, P=0.77$, two-sided Fisher's exact test). In the validation cohort, however, significance could not be achieved as to whether malformations were more frequent in women $(1.7 \%)$ than men $(0.63 \%)$ with HD (OR: 2.70 , 95\% CI 0.58-13.63, $P=0.27$, two-sided Fisher's exact test). There was no significant difference in frequency between the proportion of women in the HD and non-HD cohorts in

Table 5 Associations with malformation in both cohorts

\begin{tabular}{lcl}
\hline Characteristic & Odds ratio $(95 \%$ CI $)$ & $P$ \\
\hline All participants (HD and non-HD), $n=3918$ & \\
HD status & $5.12(2.25-11.66)$ & $9.9 \times 10^{-5}$ \\
Age at death & $1.01(0.98-1.03)$ & 0.60 \\
Sex & $1.37(0.66-2.85)$ & 0.40 \\
HD only, $n=711$ & \\
Age at death & $0.99(0.96-1.03)$ & 0.68 \\
Sex & $4.56(1.27-16.3)$ & 0.020 \\
Non-HD only, $n=3207$ & $1.03(0.99-1.08)$ & \\
Age at death & $0.44(0.15-1.32)$ & 0.17 \\
Sex &
\end{tabular}

Binary logistic regression with malformation as dependent variable. $\mathrm{HD}$ status was dichotomized as $\mathrm{HD}=1$, non-HD $=0$ and sex as female $=1$, male $=0$ either the discovery or validation cohorts (Supplementary Table 1).

Values for CAG repeat expansion in the HTT gene were available for $102 \mathrm{HD}$ brains in the discovery cohort and the median expanded CAG allele was 45 (interquartile range: 5 ). In this cohort, HD brains with malformations with known CAG expansions had expanded CAG values that were typically found in the lower ranges of $\mathrm{CAG}$ repeat expansion (CAG: 40-52).

We next sought to model the clinicopathologic associations with malformations using binary logistic regression on both cohorts combined (Table 5). Overall, malformations were significantly associated with HD (OR 5.12, 95\% CI $2.25-11.66, P<0.0001)$, but not with age at death or sex. When only HD individuals were assessed, women significantly associated with malformations (OR 4.56, 95\% CI 1.27-16.3, $P=0.020$ ), whereas age at death was not significant (OR $0.99,95 \%$ CI $0.96-1.03, P=0.68$ ). No significant difference between the age at death (OR 1.03, 95\% CI $0.99-1.08, P=0.17$ ) or sex (OR $0.44,95 \%$ CI $0.15-1.32$, $P=0.14$ ) was found in the non-HD participants.

\section{Pathologic features of malformations in the HD groups}

Slides and formalin-fixed paraffin-embedded blocks of cases \#1-20 of the NYBB discovery cohort were available for reassessment. Additional sections of cases \#1-5, \#7-8, \#13, $\# 16$, and \#18 were immunohistochemically stained against Huntingtin and p62.

The periventricular nodular heterotopias $(\mathrm{PNH})$ in $\mathrm{HD}$ cases \#1 (Fig. 1), \#2-3 (Fig. 2), and \#8 (Fig. 5c) were morphologically similar to those found in non-HD brains (supplemental Fig. 1) and comprised a population of

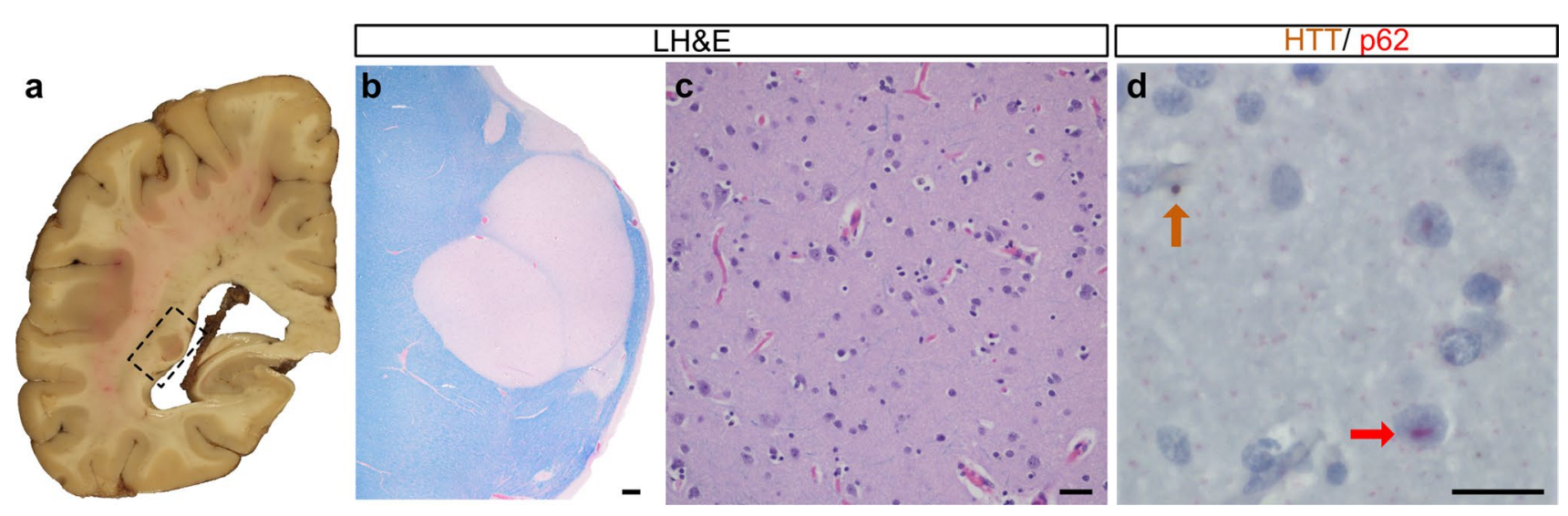

Figure 1: Macroscopic and microscopic photographs of a 41-year-old woman (CAG: 47/14) with a PNH (case \#1). a The PNH in case 1 is beneath the ependymal lining of the left atrium (dashed rectangle outlines the malformation). b This multinodular heterotopia is surrounded by myelinated fibers. $\mathbf{c}$ The heterotopia comprises non-dys- morphic neurons with haphazardly arranged apical dendrites amongst oligodendrocytes and astrocytes. d This heterotopia harbored HTT and p62 aggregates. Brown arrows indicate HTT aggregates; red arrows indicate p62 aggregates. Stains: b, c LH\&E; d HTT/p62 immunostain. Scale bars: b $200 \mu \mathrm{m}$; c $50 \mu \mathrm{m}$; d $20 \mu \mathrm{m}$. 


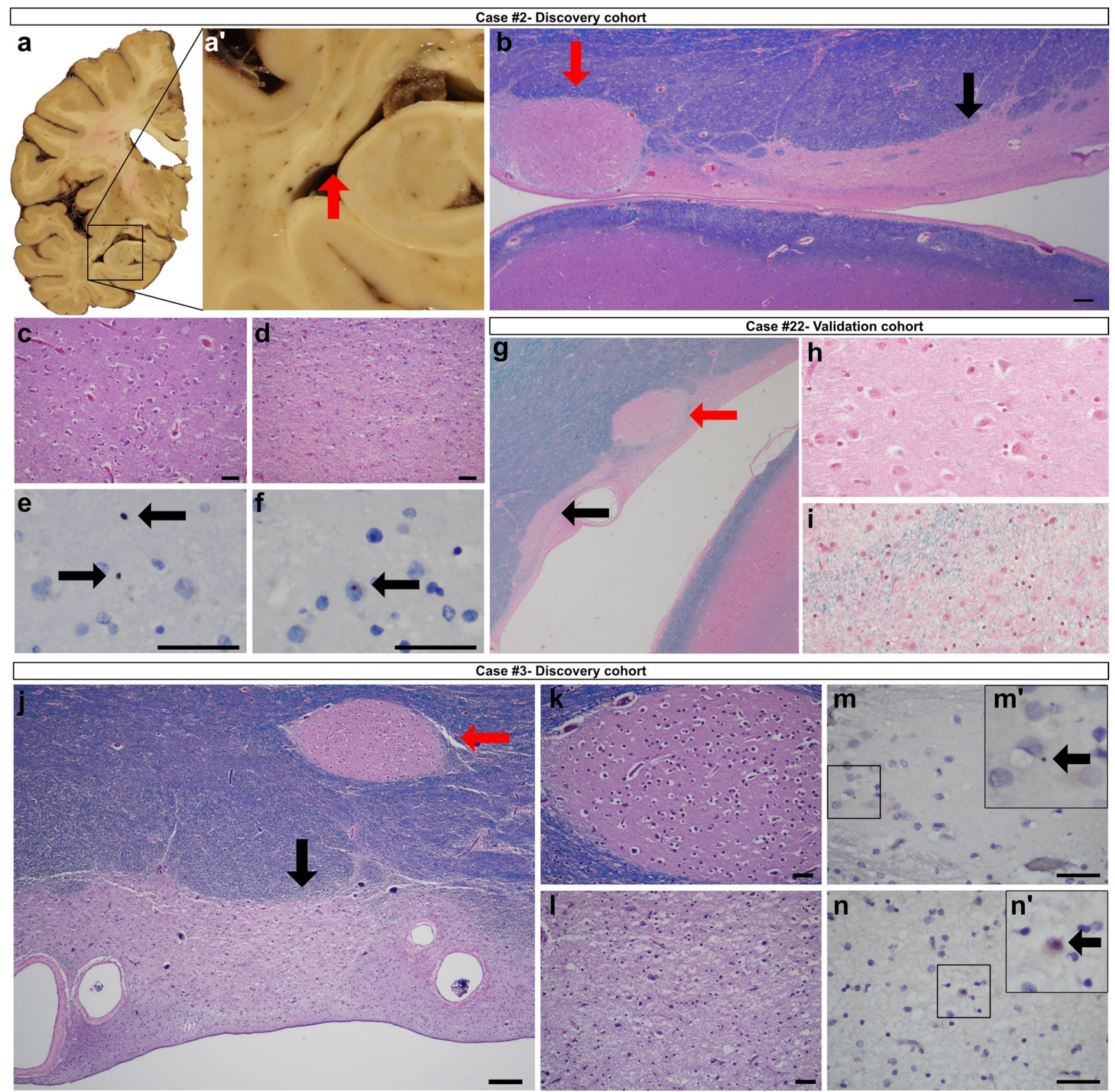

Figure 2: Three examples of individuals with HD (cases \#2, \#3, and \#22) that have PNH around the temporal horn of the lateral ventricle. In all three instances, the tail of the caudate nucleus (black arrow) is severely atrophic, whilst the nearby heterotopia (red arrow) appears relatively spared of injury. a Coronal slice of the left cerebral hemisphere at the level of the mammillary body revealing a flattened body of the caudate nucleus with atrophy of the lenticular nucleus and a focal nodule protruding into the temporal horn of the lateral ventricle (red arrow, a'). b A photomicrograph of an LH\&E-stained section indicating the ovoid heterotopia. The heterotopia (red arrow) is in close proximity to the atrophic tail of the caudate nucleus (black arrow). c, d In contrast to the tail of the caudate nucleus (d), the heterotopia (c) does not show neuronal loss or gliosis, but a collection of neurons and glia. The tail of the caudate nucleus is without neurons but with fibrillary gliosis. e, f Similar to the neocortex of this case (not shown), both HTT (e) and p62 (f) aggregates are found within the heterotopia. g In case \#22, the heterotopia (red arrow) is seen adjacent to the tail of the caudate nucleus (black arrow). $\mathbf{h}, \mathbf{i}$ The tail of the caudate (i) shows gliosis and neuronal loss in contrast to the relatively spared heterotopia (h). $\mathbf{j}-\mathbf{l}$ In case \#3, the tail of the caudate nucleus (black arrow) shows neuronal loss and fibrillary gliosis (l) in contrast to the oval-shaped heterotopia (k). m, n HTT (brown chromagen, m' inset) and p62 aggregates (red chromagen, n' inset) were found in the heterotopia and adjacent tail of caudate nucleus, respectively. Scale bars: b, j $200 \mu \mathrm{m} ; \mathbf{c}-\mathbf{f}, \mathbf{k}-\mathbf{n} 50 \mu \mathrm{m}$. 
non-dysmorphic, pyramidal-shaped neurons intermixed with monomorphic glial cells. The neuropil of these nodules lacked gliosis or evidence of neuronal degeneration. One of the striking histologic findings seen in cases \#2, \#3, \#8 (discovery cohort) and \#22 (validation cohort) was the distinct contrast between the bland appearance of the heterotopia and the severe gliosis and neuronal loss seen in the adjacent tail of the caudate nucleus (Fig. 2b-d, g-1). However, p62/ HTT inclusions were found in both the heterotopias and in the tail of the caudate nuclei (Fig. 2e-f, m, n). Neurofibrillary tangles were absent in the heterotopias in cases \#1-3 and \#8 by LH\&E and p62 immunostaining. In contrast to heterotopias found in the HD brains, heterotopias of non-HD cases did not show HTT aggregates $(n=3$, Supplemental Table 1). However, tau-related and synuclein-related aggregates were seen depending on the respective comorbid neurodegenerative conditions as previously described [12, 31]. Accordingly, p62 aggregates reflective of the specific brain proteinopathy were seen in these heterotopias.

The subcortical malformation of case \#5 differed with the PNH by morphology and immunohistochemistry. This lobulated mass comprised well-circumscribed foci of immature neurons intermixed with glial cells that were surrounded by a vacuolated neuropil (Fig. 3a, c). A subset of neurons exhibited intracytoplasmic vacuoles. Neither gliosis nor infiltration of the surrounding parenchyma was seen. This morphology was consistent with a multinodular and vacuolating neuronal tumor of the cerebrum (MVNT) [29]. NeuN immunostaining highlighted differentiated neurons within the neighboring cortex; however, the neurons within the malformation were negative (not shown), consistent with the immature neuronal development that is characteristic of MVNT. Moreover, immunohistochemistry failed to detect pathologic HTT or p62 aggregates within this malformation in contrast to that seen in the nearby neocortex (Fig. 3d-g).

Case \#4 revealed a $0.7 \mathrm{~cm}$ firm, tan, solid mass with a smooth surface involving the tuber cinereum (Fig. 4a, b). This nodule was composed of a mixture of glia and nondysmorphic neurons, a subset of which exhibited neurofibrillary tangles (Fig. 4c, d). The location of this mass and its histomorphology was consistent with that of a hypothalamic hamartoma [15]. Immunostaining against p62 identified neurofibrillary tangles and neuropil threads (Fig. 4e); however, no HTT aggregates were detected by immunohistochemistry (Fig. 4f).

A focal collection of mature, ovoid neurons, and glial cells were present in the subcortical white matter ventral to the dentate nucleus in case \#6. Case \#7 had a subcortical nodule of mature Purkinje-like neurons and glial cells within the album cerebelli. There were no HTT or p62 inclusions identified within this heterotopia nor in the cerebellar cortex by immunohistochemistry.
The whole brain of case \#8 was fixed and each half was processed according to the same protocol for comparing laterality of the cerebral hemispheres (Fig. 5). A PNH (Fig. 5c, e, g) and a malformation in the insular cortex (Fig. 5j, 1, n) were found in the right cerebral hemisphere. The $1 \times 1 \mathrm{~mm}$ circumscribed insular malformation appeared as a focal disorganization of the laminar architecture in the infragranular layers of the cortex (Fig. 5j). This malformation was composed of a collection of haphazard, enlarged, pleomorphic glial cells spread amongst closely apposed neurons with hyperchromatic nuclei. Neither neuronal dysmorphism nor balloon cells were evident. CD34 immunostaining demonstrated a cluster of cells with bushy processes (Fig. $5 \mathrm{n}$ ), confirming cellular immaturity within this malformation. HTT and p62 aggregates were not seen in the anomaly; however, they were found in the nearby neocortex. Altogether, the histomorphology appeared most consistent with that of a glial microhamartoma (alternatively known as a glial heterotopia) that has been described in the context of neurofibromatosis type 2 (NF2) [53,65]. This individual did not have a history of NF2 nor other stigmata of the syndrome at post-mortem examination.

\section{Discussion}

By examining two large, independent autopsy cohorts, we demonstrate an increased frequency of malformations in the brains of individuals with HD and thus provide further evidence that pathogenic trinucleotide repeat expansions of the HTT gene may impact neurodevelopment. The majority of these malformations in HD were PNH (10 of 15) and appeared asymmetric at macroscopic examination, suggesting that these may have developed secondary to a postzygotic somatic mutation or another developmental disruption [48]. Malformations were found in patients with varied disease severity and were individuals with adult-onset of motor signs that had HTT repeat expansions between 40 and $52 \mathrm{CAG}$ repeats. In both of our HD cohorts, women more frequently harbored malformations than men, thereby suggesting the possible presence of sexual dimorphism in specific developmental contexts, such as malformations within the rostral neuraxis.

These malformations would have formed early during neurodevelopment and before the clinical onset of HD. The increased occurrence of malformations in HD brains therefore reflects a focal disturbance in usual brain development caused by $H T T$ gene expansion rather than as a consequence of clinical disease. However, the pathogenic HTT-related deleterious process may be occurring earlier and closer to the timing of neurodevelopmental events than previously envisaged. Well documented are the subtle clinicopathologic changes that occur before the clinical disease onset; 
Figure 3: Histopathology of case \#5. a Photomicrograph of the multinodular vacuolating tumor of the cerebrum (MVNT) that is surrounded by white matter and rests beneath the prefrontal cortex (BA9). b, c

The malformation is vacuolated (c) in contrast to the infragranular layers of the nearby prefrontal cortex (b). $\mathbf{d}-\mathbf{g}$ In contrast to the prefrontal cortex, which has many HTT (d) and p62 aggregates (f), the MVNT has none $(\mathbf{e}, \mathbf{g})$. Arrows indicate aggregates. Scale bars: a 200 $\mu \mathrm{m} ; \mathbf{b}, \mathbf{c} 50 \mu \mathrm{m} ; \mathbf{d}-\mathbf{g} 20 \mu \mathrm{m}$.

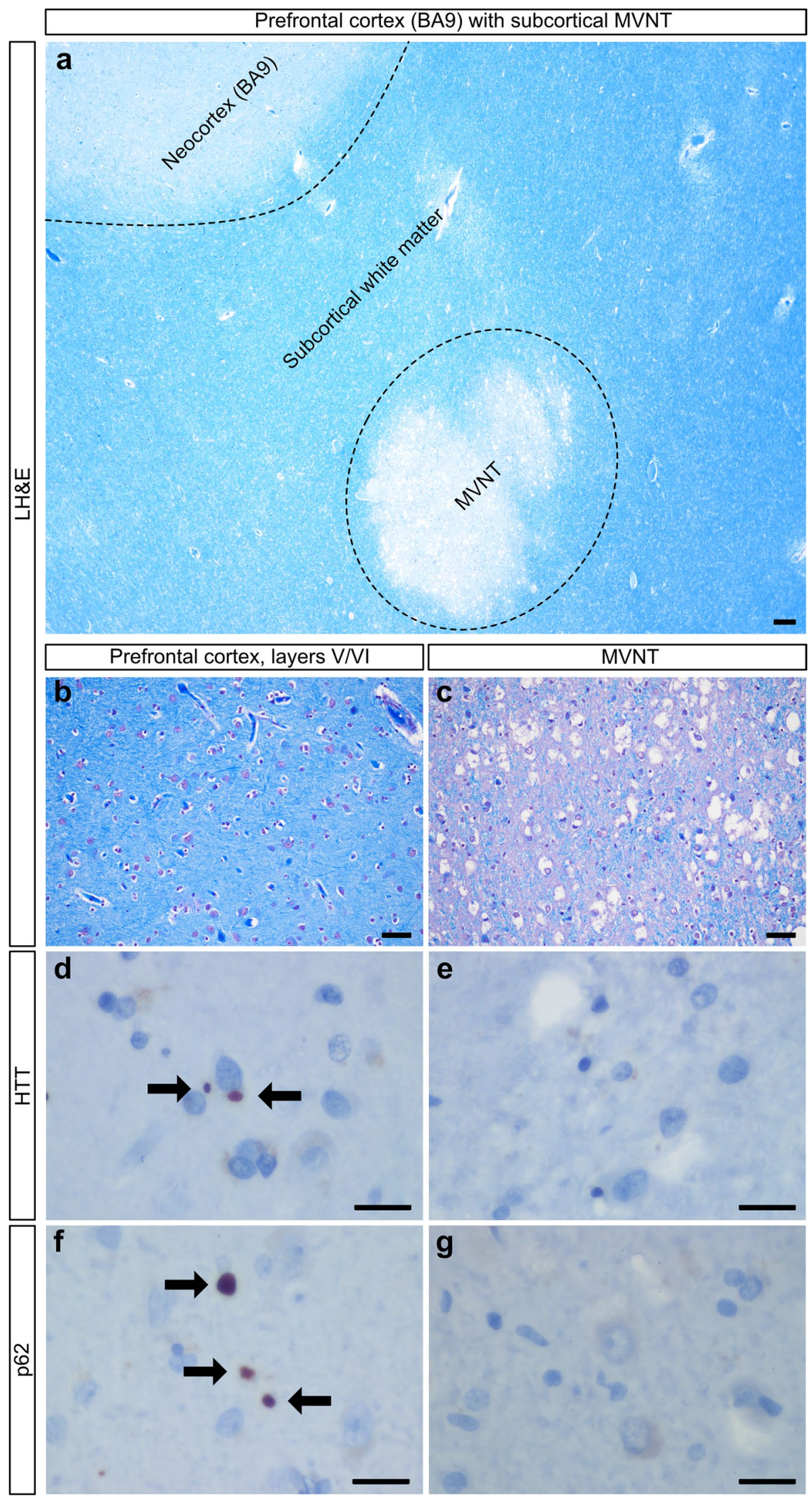



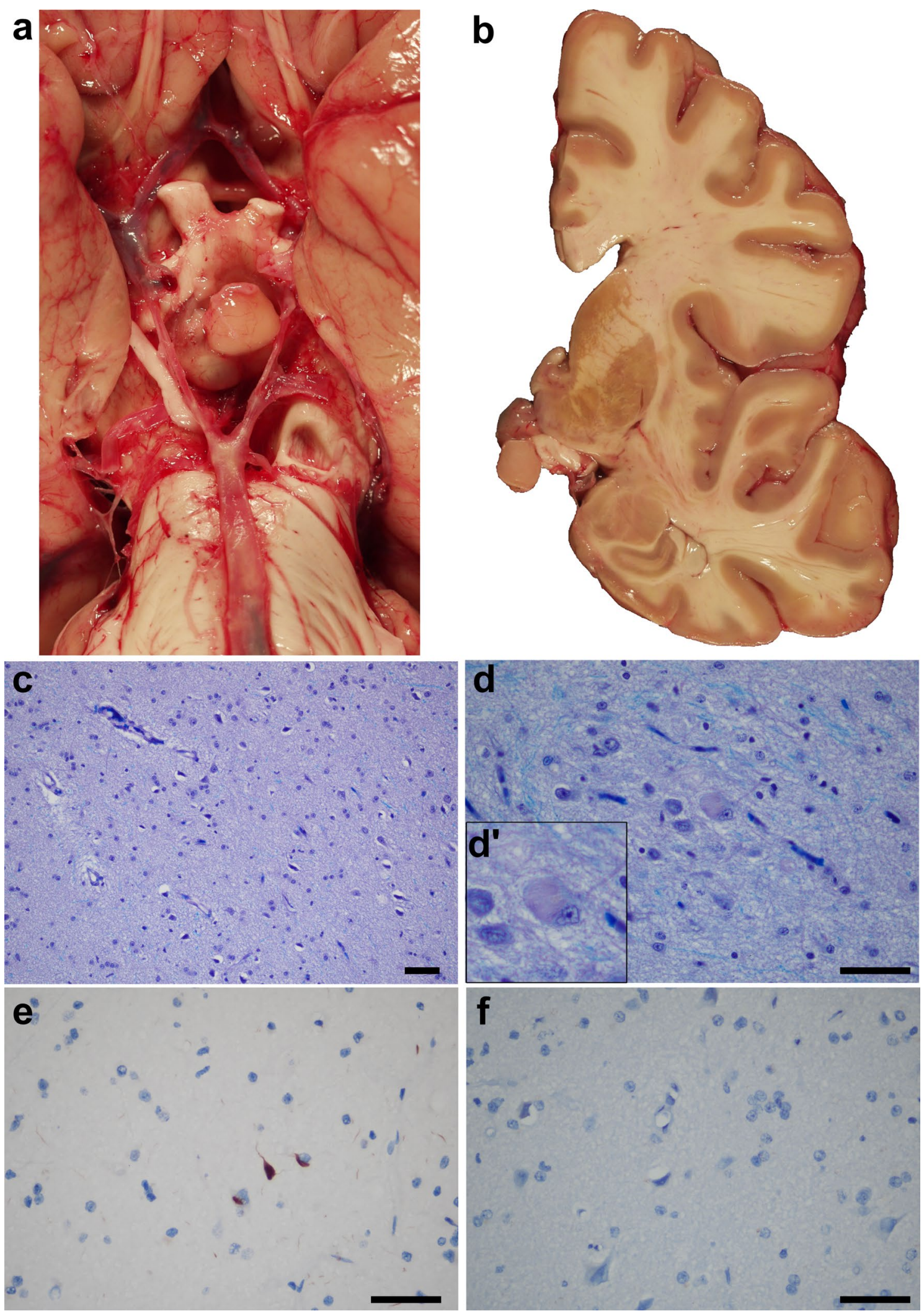

premanifest carriers with pathogenic $H T T$ gene expansion show striatal atrophy, cortical thinning, focally increased oligodendrocyte densities, and demonstrate cognitive and 
4Figure 4: Macroscopic and microscopic photographs of the hypothalamic hamartoma of case \#4. a, b A $0.7 \mathrm{~cm}$, tan, round, firm nodule was noticed in the tuber cinereum next to the hypothalamus in the fresh state. The head of the caudate nucleus shows mild atrophy and retains the normal, medial convexity (HD grade: 2/4). c, d LH\&Estained sections show a solid glioneuronal mass with haphazardly arranged neurons and intermixed glia (c). Occasional neurofibrillary tangles are seen (d, d' inset). e, f Whilst a p62 immunostain highlights tangles and neuropil threads within the lesion (e), the HTT immunostain is negative for aggregates (f). Scale bars: $50 \mu \mathrm{m}$

behavioral changes that can occur up to several decades prior to the onset of motor signs [19, 26, 46, 49, 58].

We found 5 types of developmental malformations that were hitherto not associated with HD and PNH were the most common. Many molecular mechanisms regulating heterotopia formation are recognized, and the etiology includes both genetic aberrations and epigenetic phenomena. Filamin A (FLNA) mutations are the most well-known cause of PNH. FLNA is an actin-binding protein that is cell autonomous in neuronal migration by its expression in cortical precursors. Inheritance of an X-linked mutation of the FLNA gene causes bilateral PNH in females or lethality in males, whereas missense mutations that functionally result in hypomorphic alleles lead to viable males and focal PNH in females [23, 44, 55]. Such a missense mutation in FLNA could produce the focal PNH in the HD women in this study (cases \#1-3, 8, 22, 24, 26-27). In MVNT, a malformation that was identified in HD case \#5, mutations in genes involved in the MAP kinase pathway have been reported [50]. This increased frequency of malformations in HD may be caused by disease-related genomic instability as a result of $H T T$ gene expansion [1, 33, 34, 43, 57]. The rate of somatic mutation is high during neurogenesis at approximately 5.1 single-nucleotide variants per progenitor per day and pathogenic mutations during this period may cause malformations [7, 17]. HTT is implicated in DNA repair and, if this is partially defective through $H T T$ gene expansion, this could further increase the frequency of postzygotic somatic mutations in neuronal precursors and lead to an increased occurrence of malformations in GEC [22, 24, 30, 37, 39, 40, 51].

However, loss-of-function of HTT may also play a role. Clearly, the developmental biology of HTT species, its modifications, protein interactors, and molecular pathway effectors are critical for establishing the dynamic scaffolds necessary for cortical organization (summarized in [54]). Supporting the loss-of-function hypothesis, the murine HTT hypomorph model investigated by Arteaga-Bracho and colleagues developed subpallial heterotopias and, later in life, striatal neurodegeneration [5]. Moreover, Barnat et al. have demonstrated abnormal localization of HTT and junctional complexes within neural progenitor cells at 13 week gestational age in human fetal GEC [10]. Such junctions are crucial for apicobasal polarity within the neuroepithelium and for cellular cohesion. If perturbed, this could affect neuronal migration and also lead to heterotopia formation [21, $36,56,61]$.

The variety and differing pathogenesis of these malformations provides further insight into the neurodegenerative aspects of HD. The relative sparing of neurodegeneration within the PNH in the roof of the temporal horn was in stark contrast to the nearby atrophic tail of the caudate nucleus and emphasizes the selective vulnerability of cell types and connections in HD, particularly the neostriatal medium spiny neurons. Furthermore, the presence of HTT/ p62 aggregates in $\mathrm{PNH}$ is similar to that of the HD neocortex. This occurrence is expected as these heterotopic neurons would have been destined for the cortex which is usually rich in aggregates. Moreover, this would also explain why definite neuronal loss is not obvious in the PNH compared to the adjacent neostriatum; although the HD neocortex undergoes neuronal loss, it occurs to a lesser extent than that seen in the neostriatum.

In contrast to the $\mathrm{PNH}$, aggregates were not found within the MVNT, hypothalamic hamartoma, cerebellar heterotopia, and glial microhamartoma of HD brains. This likely reflects the different neuronal subtypes within the respective malformation and/or the different stages of neuronal development within these anomalies. For example, the vacuolated neurons of MVNT usually express OLIG2 but not NeuN, which has led to the hypothesis that these cells may be the sequela of interrupted development of neural progenitor cells [59]. Furthermore, the presence of CD34, a stem cell marker expressed during neurulation, in the glial microhamartoma (case \#8) indicates cellular immaturity within this malformation and might explain why aggregates do not occur within these cells in contrast to those of the adjacent cortex [13].

The reduced detection of malformations in HD in the validation cohort than the discovery cohort is to some extent due to the differential processing methods between the two centers and the cumulative experience over time. In the discovery cohort at the NYBB, trained pathologists examine the macroscopic slices of both halves of the brain, whereas only one fixed half brain was usually examined by a neuropathologist in the validation cohort [62]. Furthermore, the standardized series of blocks obtained for the microscopic examination of most half brains in the validation cohort utilized only 14 blocks, whereas four additional blocks were taken in the discovery cohort. Therefore, this greater sampling and professional experience in the discovery cohort increases the probability of detecting malformations.

There are limitations to this study. Given that HD is heritable, it is possible that some of the brains with malformations are related and thus share common genes that predispose for such anomalies, thereby biasing the HD cohort. 


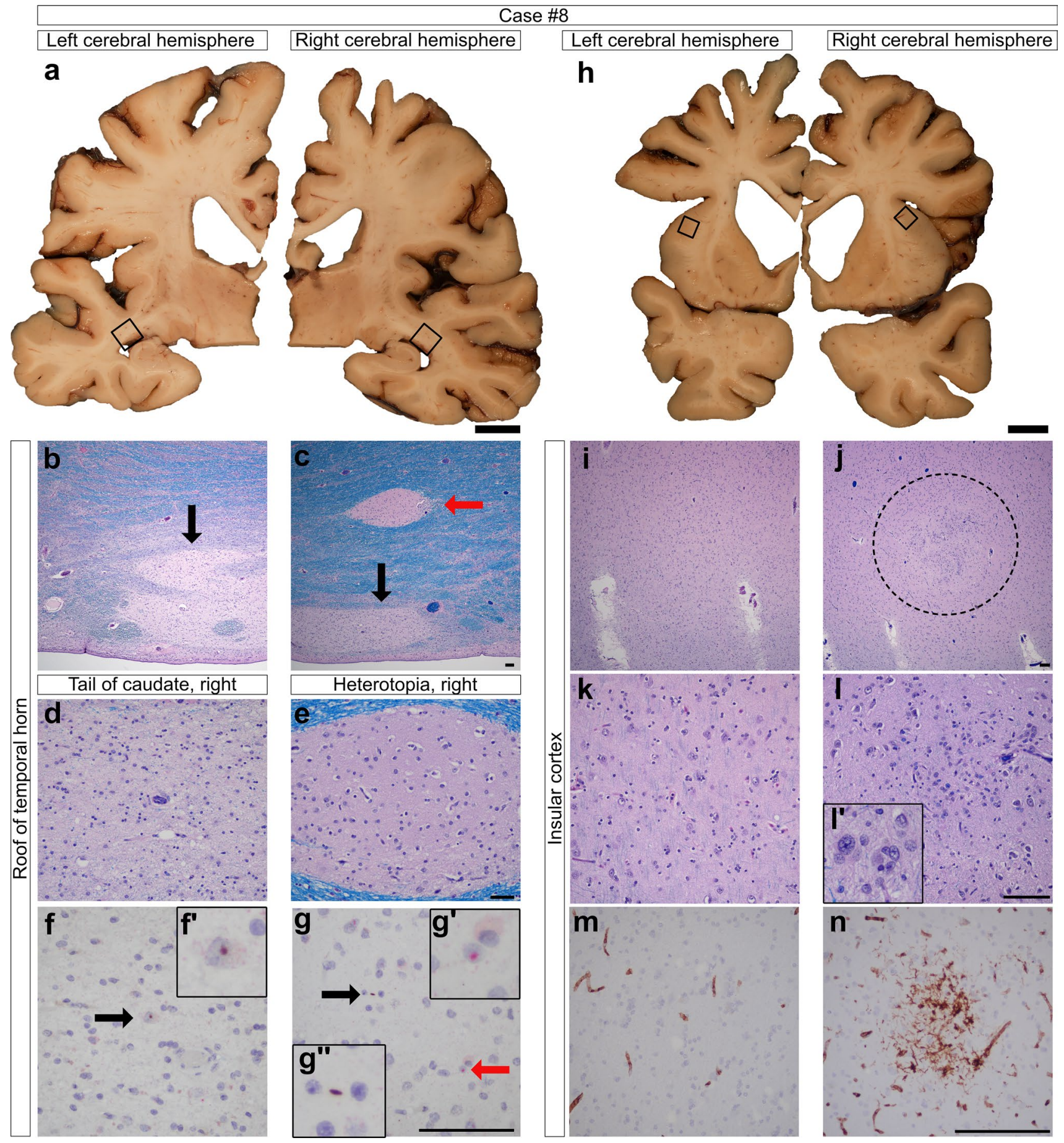

Figure 5: Macroscopic and microscopic photographs of case \#8. a-g At the level of the lateral geniculate body, a PNH (red arrow, c) is noted above the atrophic tail of the caudate nucleus (black arrow, c), but not in the left cerebral hemisphere (b). Similar to the other PNH in HD, the heterotopia (e) shows relative sparing of neurodegeneration in comparison to the nearby tail of the caudate nucleus (d) and demonstrates p62 (red arrow, g and g' inset) and HTT aggregates (black arrow, g' inset). An intranuclear HTT aggregate is shown in

the tail of the caudate nucleus (black arrow, $\left.f, f^{\prime}\right)$. h-n At the level of the nucleus accumbens, an abnormal cluster of cells is noted in the right insular cortex (dashed circle, $\mathbf{j}, \mathbf{l}$ ). An inset (l') shows enlarged glial cells and a neuron within the focus. A CD34 immunostain highlights immature cells with bushy processes within this malformation (n). The corresponding side on the left insular cortex is provided for comparison (I, k, m). Note the severe cortical atrophy in this HD brain. Scale bars a, h: $1 \mathrm{~cm} ; \mathbf{b}-\mathbf{n} 100 \mu \mathrm{m}$. 
Review of the medical charts did not reveal any association of heterotopias between siblings. Birth and maternal histories were unavailable. Furthermore, brains received at a brain bank may be subject to referral bias, such that patients with diagnostically interesting or unusual presentations may be encouraged to consent for brain donation. This is unavoidable, although using a validation cohort of a much larger size based from a different region of the United States of America, we have aimed to overcome this potential bias. Finally, we cannot provide a potential biological mechanism by employing these formalin-fixed tissue samples.

In conclusion, we document an increased frequency of neurodevelopmental malformations in the HD brain compared to non-HD brains in the largest neuropathologic series of HD to date that spans a period of nearly 40 years. We further demonstrated that cortical malformations of the cerebrum that contain mature neurons were susceptible to HTT/ p62 aggregation, whereas those with immature neuronal populations lacked such aggregates. Whether more subtle neurodevelopmental abnormalities are occurring in the HD brain is conceivable and merits further study.

Supplementary Information The online version contains supplementary material available at https://doi.org/10.1007/s00401-021-02269-4.

Acknowledgements RAH is supported by grant funding from the Huntington Disease Society of America and Hereditary Disease Foundation and is a Columbia University Irving Medical Center ADRC Research Education Component trainee (P30 AG066462-01 PI: Small, Scott, MD). The New York Brain Bank is supported by P50 AG008702 (PI Scott Small, MD). We extend our sincere gratitude to all of the patients, families, and caregivers who were critical for accomplishing this study. In particular, we wish to thank the Hereditary Disease Foundation and Nancy Wexler for their ongoing support for HD brain banking and Gregory Suter and Norberta Robertson of the Hereditary Neurological Disease Center in Wichita, Kansas for their continuing efforts in HD brain donations over the past four decades. Gratitude is also extended to Scott Reid, Elizabeth Delaney, Anisha Viswanathan, and Drs. Roy Alcalay and Lawrence S. Honig for their coordination of HD brain donations to Columbia University Irving Medical Center. We are grateful for Xena Flowers and Dr. Christian Keller for database assistance at the NYBB and Erin McDonnell of the Department of Biostatistics, Mailman School of Public Health, Columbia University for statistical advice.

Open Access This article is licensed under a Creative Commons Attribution 4.0 International License, which permits use, sharing, adaptation, distribution and reproduction in any medium or format, as long as you give appropriate credit to the original author(s) and the source, provide a link to the Creative Commons licence, and indicate if changes were made. The images or other third party material in this article are included in the article's Creative Commons licence, unless indicated otherwise in a credit line to the material. If material is not included in the article's Creative Commons licence and your intended use is not permitted by statutory regulation or exceeds the permitted use, you will need to obtain permission directly from the copyright holder. To view a copy of this licence, visit http://creativecommons.org/licenses/by/4.0/.

\section{References}

1. (2019) CAG Repeat Not Polyglutamine Length Determines Timing of Huntington's Disease Onset. Cell 178:887-900.e814. https ://doi.org/10.1016/j.cell.2019.06.036

2. (2018) CD34 antibody- QBEND/10 https://www.bio-rad-antib odies.com/monoclonal/human-cd34-antibody-qbend-10-mca54 7.html?f=purified\&JSESSIONID_STERLING $=058$ B98689A 299BF23B7F87D8DB79FE92.ecommerce2\&evCntryLang=ATde \&cntry $=$ AT\& thirdPartyCookieEnabled $=$ true

3. (2017) Developmental alterations in Huntington's disease neural cells and pharmacological rescue in cells and mice. Nat Neurosci 20: 648-660. https://doi.org/10.1038/nn.4532

4. (2018) Periventricular heterotopia https://medlineplus.gov/genet ics/condition/periventricular-heterotopia/. Accessed 9 Jul 2020

5. Arteaga-Bracho EE, Gulinello M, Winchester ML, Pichamoorthy N, Petronglo JR, Zambrano AD, Inocencio J, De Jesus CD, Louie JO, Gokhan S et al (2016) Postnatal and adult consequences of loss of huntingtin during development: implications for Huntington's disease. Neurobiol Dis 96:144-155. https://doi. org/10.1016/j.nbd.2016.09.006

6. Auerbach W, Hurlbert MS, Hilditch-Maguire P, Wadghiri YZ, Wheeler VC, Cohen SI, Joyner AL, MacDonald ME, Turnbull DH (2001) The HD mutation causes progressive lethal neurological disease in mice expressing reduced levels of huntingtin. Hum Mol Genet 10:2515-2523. https://doi.org/10.1093/ $\mathrm{hmg} / 10.22 .2515$

7. Bae T, Tomasini L, Mariani J, Zhou B, Roychowdhury T, Franjic D, Pletikos M, Pattni R, Chen B-J, Venturini E et al (2018) Different mutational rates and mechanisms in human cells at pregastrulation and neurogenesis. Science (New York, NY) 359:550-555. https://doi.org/10.1126/science.aan8690

8. Barkovich A, Kjos B (1992) Gray matter heterotopias: MR characteristics and correlation with developmental and neurologic manifestations. Radiology 182:493-499

9. Barkovich AJ, Guerrini R, Kuzniecky RI, Jackson GD, Dobyns WB (2012) A developmental and genetic classification for malformations of cortical development: update 2012. Brain 135:1348-1369

10. 10Barnat M, Capizzi M, Aparicio E, Boluda S, Wennagel D, Kacher R, Kassem R, Lenoir S, Agasse F, Braz BY (2020) Huntington's disease alters human neurodevelopment. Science (New York, NY)

11. Bhide PG, Day M, Sapp E, Schwarz C, Sheth A, Kim J, Young AB, Penney J, Golden J, Aronin N et al (1996) Expression of normal and mutant huntingtin in the developing brain. J Neurosci 16:5523-5535. https://doi.org/10.1523/jneurosci.16-17-05523 .1996

12. Bieniek KF, Dickson DW (2015) Concurrent neurodegenerative pathologies in periventricular nodular heterotopia. Acta Neuropathol 130:895-897. https://doi.org/10.1007/s00401-015-1490-4

13. Blümcke I, Giencke K, Wardelmann E, Beyenburg S, Kral T, Sarioglu N, Pietsch T, Wolf HK, Schramm J, Elger CE (1999) The CD34 epitope is expressed in neoplastic and malformative lesions associated with chronic, focal epilepsies. Acta Neuropathol 97:481-490

14. 14Brodmann K (1909) Vergleichende Lokalisationslehre der Grosshirnrinde in ihren Prinzipien dargestellt auf Grund des Zellenbaues. Barth, City

15. Coons SW, Rekate HL, Prenger EC, Wang N, Drees C, Ng Y-t, Chung SS, Kerrigan JF (2007) The histopathology of hypothalamic hamartomas: study of 57 cases. J Neuropathol Exp Neurol $66: 131-141$ 
16. Croce KR, Yamamoto A (2019) A role for autophagy in Huntington's disease. Neurobiol Dis 122:16-22. https://doi.org/10.1016/j. nbd.2018.08.010

17. 17D'Gama AM, Walsh CA (2018) Somatic mosaicism and neurodevelopmental disease. Nat Neurosci 21:1504-1514

18. Dehay B, Weber C, Trottier Y, Bertolotti A (2007) Mapping of the epitope of monoclonal antibody $2 \mathrm{~B} 4$ to the proline-rich region of human Huntingtin, a region critical for aggregation and toxicity. Biotechnol J 2:559-564. https://doi.org/10.1002/biot.200600249

29. Duff K, Paulsen JS, Beglinger LJ, Langbehn DR, Stout JC, Group P-HIotHS (2007) Psychiatric symptoms in Huntington's disease before diagnosis: the predict-HD study. Biol Psychiatry 62:1341-1346

20. Duyao MP, Auerbach AB, Ryan A, Persichetti F, Barnes GT, McNeil SM, Ge P, Vonsattel JP, Gusella JF, Joyner AL et al (1995) Inactivation of the mouse Huntington's disease gene homolog Hdh. Science (New York, NY) 269:407-410. https:// doi.org/10.1126/science.7618107

21. Ferland RJ, Batiz LF, Neal J, Lian G, Bundock E, Lu J, Hsiao Y-C, Diamond R, Mei D, Banham AH et al (2009) Disruption of neural progenitors along the ventricular and subventricular zones in periventricular heterotopia. Human Mol Genet 18:497-516. https://doi.org/10.1093/hmg/ddn377

22. Ferlazzo ML, Sonzogni L, Granzotto A, Bodgi L, Lartin O, Devic C, Vogin G, Pereira S, Foray N (2014) Mutations of the Huntington's disease protein impact on the ATM-dependent signaling and repair pathways of the radiation-induced DNA double-strand breaks: corrective effect of statins and bisphosphonates. Mol Neurobiol 49:1200-1211. https://doi.org/10.1007/s12035-013-8591-7

23. Fox JW, Lamperti ED, Ekşioğlu YZ, Hong SE, Feng Y, Graham DA, Scheffer IE, Dobyns WB, Hirsch BA, Radtke RA et al (1998) Mutations in filamin 1 prevent migration of cerebral cortical neurons in human periventricular heterotopia. Neuron 21:1315-1325. https://doi.org/10.1016/s0896-6273(00)80651-0

24. Gao R, Chakraborty A, Geater C, Pradhan S, Gordon KL, Snowden J, Yuan S, Dickey AS, Choudhary S, Ashizawa T et al (2019) Mutant huntingtin impairs PNKP and ATXN3, disrupting DNA repair and transcription. Elife. https://doi.org/10.7554/eLife .42988

25. Godin JD, Colombo K, Molina-Calavita M, Keryer G, Zala D, Charrin BC, Dietrich P, Volvert ML, Guillemot F, Dragatsis I et al (2010) Huntingtin is required for mitotic spindle orientation and mammalian neurogenesis. Neuron 67:392-406. https://doi. org/10.1016/j.neuron.2010.06.027

26. Gómez-Tortosa E, MacDonald ME, Friend JC, Taylor SA, Weiler LJ, Cupples LA, Srinidhi J, Gusella JF, Bird ED, Vonsattel JP (2001) Quantitative neuropathological changes in presymptomatic Huntington's disease. Ann Neurol 49:29-34

27. Herndon ES, Hladik CL, Shang P, Burns DK, Raisanen J, White CL 3rd (2009) Neuroanatomic profile of polyglutamine immunoreactivity in Huntington disease brains. J Neuropathol Exp Neurol 68:250-261. https://doi.org/10.1097/NEN.0b013e318198d320

28. Hickman RA, Flowers XE, Wisniewski T (2020) Primary agerelated tauopathy (PART): addressing the spectrum of neuronal tauopathic changes in the aging brain. Curr Neurol Neurosci Rep 20:1-11

29. Huse JT, Edgar M, Halliday J, Mikolaenko I, Lavi E, Rosenblum MK (2013) Multinodular and vacuolating neuronal tumors of the cerebrum: 10 cases of a distinctive seizure-associated lesion. Brain Pathol 23:515-524

30. Jamuar SS, Lam A-TN, Kircher M, D’Gama AM, Wang J, Barry BJ, Zhang X, Hill RS, Partlow JN, Rozzo A (2014) Somatic mutations in cerebral cortical malformations. N Engl J Med 371:733-743

31. Joseph JT (1997) Periventricular heterotopias display cortical degenerative neuropathology. Neurology 49:884-887
32. Keller CE, Del Amaya MP, Cortes EP, Mancevska K, Vonsattel JPG (2008) Electronic tracking of human brain samples for research. Cell Tissue Banking 9:217-227

33. Kennedy L, Evans E, Chen CM, Craven L, Detloff PJ, Ennis M, Shelbourne PF (2003) Dramatic tissue-specific mutation length increases are an early molecular event in Huntington disease pathogenesis. Hum Mol Genet 12:3359-3367. https://doi. org/10.1093/hmg/ddg352

34. Kennedy L, Shelbourne PF (2000) Dramatic mutation instability in HD mouse striatum: does polyglutamine load contribute to cellspecific vulnerability in Huntington's disease? Hum Mol Genet 9:2539-2544. https://doi.org/10.1093/hmg/9.17.2539

35. Lee JK, Mathews K, Schlaggar B, Perlmutter J, Paulsen JS, Epping E, Burmeister L, Nopoulos P (2012) Measures of growth in children at risk for Huntington disease. Neurology 79:668-674. https://doi.org/10.1212/WNL.0b013e3182648b65

36. Lian G, Sheen VL (2015) Cytoskeletal proteins in cortical development and disease: actin associated proteins in periventricular heterotopia. Front Cell Neurosci. https://doi.org/10.3389/fncel .2015 .00099

37. Lodato MA, Rodin RE, Bohrson CL, Coulter ME, Barton AR, Kwon M, Sherman MA, Vitzthum CM, Luquette LJ, Yandava CN (2018) Aging and neurodegeneration are associated with increased mutations in single human neurons. Science (New York, NY) 359:555-559

38. MacDonald ME, Ambrose CM, Duyao MP, Myers RH, Lin C, Srinidhi L, Barnes G, Taylor SA, James M, Groot N (1993) A novel gene containing a trinucleotide repeat that is expanded and unstable on Huntington's disease chromosomes. Cell 72:971-983

39. Maiuri T, Bowie LE, Truant R (2019) DNA repair signaling of huntingtin: the next link between late-onset neurodegenerative disease and oxidative DNA damage. DNA Cell Biol 38:1-6. https ://doi.org/10.1089/dna.2018.4476

40. Maiuri T, Mocle AJ, Hung CL, Xia J, van Roon-Mom WM, Truant $R$ (2017) Huntingtin is a scaffolding protein in the ATM oxidative DNA damage response complex. Hum Mol Genet 26:395-406. https://doi.org/10.1093/hmg/ddw395

41. Marder K, Mehler MF (2012) Development and neurodegeneration: turning HD pathogenesis on its head. Neurology 79:621622. https://doi.org/10.1212/WNL.0b013e3182648bfe

42. Mehler MF, Petronglo JR, Arteaga-Bracho EE, Gulinello ME, Winchester ML, Pichamoorthy N, Young SK, DeJesus CD, Ishtiaq H, Gokhan S et al (2019) Loss-of-Huntingtin in medial and lateral ganglionic lineages differentially disrupts regional interneuron and projection neuron subtypes and promotes Huntington's disease-associated behavioral, cellular, and pathological hallmarks. J Neurosci 39:1892-1909. https://doi.org/10.1523/jneur osci.2443-18.2018

43. Mouro Pinto R, Arning L, Giordano JV, Razghandi P, Andrew MA, Gillis T, Correia K, Mysore JS, Grote Urtubey D-M, Parwez CR (2020) Patterns of CAG repeat instability in the central nervous system and periphery in Huntington's disease and in spinocerebellar ataxia type 1. Human Mol Genet 29:2551-2567

44. Nagano T, Yoneda T, Hatanaka Y, Kubota C, Murakami F, Sato M (2002) Filamin A-interacting protein (FILIP) regulates cortical cell migration out of the ventricular zone. Nat Cell Biol 4:495501. https://doi.org/10.1038/ncb808

45. Nasir J, Floresco SB, O'Kusky JR, Diewert VM, Richman JM, Zeisler J, Borowski A, Marth JD, Phillips AG, Hayden MR (1995) Targeted disruption of the Huntington's disease gene results in embryonic lethality and behavioral and morphological changes in heterozygotes. Cell 81:811-823. https://doi.org/10.1016/00928674(95)90542-1

46. Nopoulos P, Magnotta VA, Mikos A, Paulson H, Andreasen NC, Paulsen JS (2007) Morphology of the cerebral cortex in preclinical 
Huntington's disease. Am J Psychiatry 164:1428-1434. https:// doi.org/10.1176/appi.ajp.2007.06081266

47. Nopoulos PC, Aylward EH, Ross CA, Mills JA, Langbehn DR, Johnson HJ, Magnotta VA, Pierson RK, Beglinger LJ, Nance MA et al (2011) Smaller intracranial volume in prodromal Huntington's disease: evidence for abnormal neurodevelopment. Brain 134:137-142. https://doi.org/10.1093/brain/awq280

48. Oegema R, Barkovich AJ, Mancini GMS, Guerrini R, Dobyns WB (2019) Subcortical heterotopic gray matter brain malformations: Classification study of 107 individuals. Neurology. https://doi. org/10.1212/wnl.0000000000008200

49. Paulsen JS, Nopoulos PC, Aylward E, Ross CA, Johnson H, Magnotta VA, Juhl A, Pierson RK, Mills J, Langbehn D (2010) Striatal and white matter predictors of estimated diagnosis for Huntington disease. Brain Res Bull 82:201-207

50. Pekmezci M, Stevers M, Phillips JJ, Van Ziffle J, Bastian BC, Tsankova NM, Kleinschmidt-DeMasters BK, Rosenblum MK, Tihan T, Perry A et al (2018) Multinodular and vacuolating neuronal tumor of the cerebrum is a clonal neoplasm defined by genetic alterations that activate the MAP kinase signaling pathway. Acta Neuropathol 135:485-488. https://doi.org/10.1007/ s00401-018-1820-4

51. Poduri A, Evrony GD, Cai X, Walsh CA (2013) Somatic mutation, genomic variation, and neurological disease. Science (New York, NY) 341:1237758. https://doi.org/10.1126/science.1237758

52. Raymond A, Fish D, Sisodiya S, Alsanjari N, Stevens J, Shorvon S (1995) Abnormalities of gyration, heterotopias, tuberous sclerosis, focal cortical dysplasia, microdysgenesis, dysembryoplastic neuroepithelial tumour and dysgenesis of the archicortex in epilepsy: clinical, EEG and neuroimaging features in 100 adult patients. Brain 118:629-660

53. 53Russell DS, Rubinstein LJ (1989) Dysplastic lesions of the central nervous system. Pathology of tumours of the nervous system. William s \& Wilkins, City, pp 776-781

54. Saudou F, Humbert S (2016) The biology of huntingtin. Neuron 89:910-926

55. Sheen VL, Dixon PH, Fox JW, Hong SE, Kinton L, Sisodiya SM, Duncan JS, Dubeau F, Scheffer IE, Schachter SC et al (2001) Mutations in the X-linked filamin 1 gene cause periventricular nodular heterotopia in males as well as in females. Hum Mol Genet 10:1775-1783. https://doi.org/10.1093/hmg/10.17.1775

56. Sheen VL, Ganesh VS, Topcu M, Sebire G, Bodell A, Hill RS, Grant PE, Shugart YY, Imitola J, Khoury SJ et al (2004) Mutations in ARFGEF2 implicate vesicle trafficking in neural progenitor proliferation and migration in the human cerebral cortex. Nat Genet 36:69-76. https://doi.org/10.1038/ng1276
57. Shelbourne PF, Keller-McGandy C, Bi WL, Yoon SR, Dubeau L, Veitch NJ, Vonsattel JP, Wexler NS, Arnheim N, Augood SJ (2007) Triplet repeat mutation length gains correlate with celltype specific vulnerability in Huntington disease brain. Hum Mol Genet 16:1133-1142. https://doi.org/10.1093/hmg/ddm054

58. Solomon AC, Stout JC, Johnson SA, Langbehn DR, Aylward EH, Brandt J, Ross CA, Beglinger L, Hayden MR, Kieburtz K (2007) Verbal episodic memory declines prior to diagnosis in Huntington's disease. Neuropsychologia 45:1767-1776

59. Thom M, Liu J, Bongaarts A, Reinten RJ, Paradiso B, Jäger HR, Reeves C, Somani A, An S, Marsdon D (2018) Multinodular and vacuolating neuronal tumors in epilepsy: dysplasia or neoplasia? Brain Pathol 28:155-171

60. van der Plas E, Langbehn DR, Conrad AL, Koscik TR, Tereshchenko A, Epping EA, Magnotta VA, Nopoulos PC (2019) Abnormal brain development in child and adolescent carriers of mutant huntingtin. Neurology 93:e1021-e1030. https://doi.org/10.1212/ wnl.0000000000008066

61. Veeraval L, O'Leary CJ, Cooper HM (2020) Adherens junctions: guardians of cortical development. Front Cell Dev Biol 8:6-6. https://doi.org/10.3389/fcell.2020.00006

62. Vonsattel JP, Del Amaya MP, Keller CE (2008) Twenty-first century brain banking. Processing brains for research: the Columbia University methods. Acta Neuropathol 115:509-532. https://doi. org/10.1007/s00401-007-0311-9

63. Vonsattel JP, Myers RH, Stevens TJ, Ferrante RJ, Bird ED, Richardson EP Jr (1985) Neuropathological classification of Huntington's disease. J Neuropathol Exp Neurol 44:559-577

64. White JK, Auerbach W, Duyao MP, Vonsattel JP, Gusella JF, Joyner AL, MacDonald ME (1997) Huntingtin is required for neurogenesis and is not impaired by the Huntington's disease CAG expansion. Nat Genet 17:404-410. https://doi.org/10.1038/ng129 7-404

65. Wiestler OD, von Siebenthal K, Schmitt HP, Feiden W, Kleihues P (1989) Distribution and immunoreactivity of cerebral micro-hamartomas in bilateral acoustic neurofibromatosis (neurofibromatosis 2). Acta Neuropathol 79:137-143. https://doi. org/10.1007/bf00294370

Publisher's Note Springer Nature remains neutral with regard to jurisdictional claims in published maps and institutional affiliations. 